\title{
The Changing Performance in the Financial System- An Empirical Brief in Innovative Services and Products of Banks
}

\author{
JAKADA, B. A \\ Lecturer at the Department of Business Administration, Bayero University Kano and Doctor of \\ Philosophy in Business Administration
}

BRUCE, A. A. A

Lecturer at the Department of Business Administration, Gombe State University and Doctor of Philosophy in Business Administration and Finance

\section{DANBAUCHI, E. S}

Lecturer at the Department of Business Administration, Gombe State University and Currently a Master

Student at Bayero University, Kano, Nigeria

Email: brucealex@gsu.edu.ng, brucealex46@gmail.com

\begin{abstract}
Financial innovation is viewed as the act of creating and popularizing new financial instruments, technologies, institutions and markets, which facilitate access to information, trading and means of payment. The paper became necessary as a result of the increased alternative payment systems which has redefined the banking operations in Nigeria and world over. We observed the twenty one (21) Deposit Money Banks licensed by the Central Bank of Nigeria as at 2016 but utilized Sixteen (16) of them purposively selected without bias for representation in terms of progressive innovation. We analyzed the annual reports, accounts, and inter-switch statistical information of the sampled Banks by measuring their performances in terms of returns on equity (ROE). The revealed evidence shows significant relationship between Automated Teller Machines transaction and financial performance while mobile transaction, internet transaction, and point of sales transaction have no significance on the financial performance of deposit money banks in Nigeria in terms of coefficients other than their joint influence even though the factoring of bank size and net interest income bears much on banks' financial performance.
\end{abstract}

Keywords: Bank Financial Performance, Innovative Products, Market Trading, Returns on Equity, Deposit Money Banks, and Progressive Innovations.

\section{Introduction}

Financial performance of banks is usually expressed as a function of internal and external determinants. The internal determinants originate from bank accounts (balance sheets and/or profit and loss accounts) and therefore could be termed micro or bank-specific determinants of performance. The external determinants are variables that are not related to bank management but reflect the economic and legal environment that affects the operation and performance of financial institutions. By extension however, financial System performance is a measure of how well a finance firm can use assets from its primary mode of business and generate incomes. It is the degree to which financial objectives are being or has been accomplished as well 
as the process of measuring the results of a firm's policies and operations in monetary terms. This term is also used as a general measure of a firm's overall financial health over a given period of time and can be used to compare similar firms across the same industry or to compare industries or sectors in aggregation (Al-Hussein \&Johnson, 2009). Financial performance measures how well a firm is generating value for the owners. It can be measured through various financial measures such as profit after tax (PAT), return on assets (ROA), return on equity (ROE), earnings per share (EPS) and any market value ratio that is generally accepted. Generally, the financial performance of banks and other financial institutions are measured using a combination of financial ratios analysis, benchmarking, measuring performance against budget or a mix of these methodologies (Ahmad,Raza, Amjad \& Akram 2011).

Current bank performance literature describes the objective of financial organizations as that of earning acceptable returns and minimizing the risks taken to earn the return (Alam, Raza \& Akram, 2011). This supports the generally accepted relationship between risk and return, that is, the higher the risk the higher the expected return and vice-versa. Perhaps, this is why the financial sector is characterized with institutions that are head-bound to develop financial products/services at all cost minimum to satisfy clients at reasonable profits even as quantum risks stand-out to threaten the system. With these cravings in the daily operations of banks, product innovations have gradually become one of the epicenters of the financial institutions in recent years - the needs to identify customer needs via Research and Development (R \& D) and the meticulous consciousness to initiate prototype products to satisfy existing needs are the calls into innovative banking. This innovative banking has of recent times blanketed all banks interested in performance achievement to device several product lines to boosting their revenue bases and to own streams of product/service offer that eases customers stress in transaction. The paper extensively surveys the most contemporary products/service lines that banks use to help them create edge against each other for maximum profit. Realistically, we examined the relationship between financial products innovation and financial performance of deposit money banks in Nigeria.

Our result showed that the general public makes more use of electronic products via the use of cards across electronic platforms/services which include Automated Teller Machines (ATMs), Internet Banking, Mobile Banking and point of sale (PoS) terminals. The increased use of electronic platforms for payments has played a significant role in the increased number of transaction volume and value in the past few years with high impact performances by the sampled banks. In the year 2014, transactions processed by the Central Inter-Switch through electronic platforms accounted for $86 \%$ of the overall transactions in terms of volume and $82 \%$ in terms of value which is an increase over the year 2013 by $6 \%$ in both transaction volume and value (CBN, 2015).

The remainder of the paper addresses the following. Section two elaborates on the theories that conceptualize financial products while emphasizing the methods and models specifications in terms of variables' proxies and relationship equations in section three. Section for presents the results and discussions while the last section concludes on the outcome of the paper.

\section{Theoretical and Empirical Modulations on Financial Products Innovation}

Financial Products innovation has evolved out of the Schumpeterian argument that new products and processes developed by a firm are protected from imitation for a certain period. A successful innovation generates a proprietary competitive position that bestows on the firm a competitive advantage and superior performance (Lyons, Chatman \& Joyce, 2007). Financial product innovations arise due to several reasons (Batiz-Lazo \& Woldesenbet, 2006). Gorton and Metrick (2010) and Batiz-Lazo and Woldesenbet (2006) summarize the reasons for the growth of modern financial innovation as to include reduction in bankruptcy costs, tax advantages, reduction in moral hazard, reduced regulatory costs, transparency and customization. Lerner (2006) asserts that financial innovations are not just critical for firms in the financial services industry, but also affect other companies; for instance, it enable them to generate larger returns at a lower cost than they could otherwise do. 
Therefore, financial innovation is viewed as the act of creating and popularizing new financial instruments, technologies, institutions and markets, which facilitate access to information, trading and means of payment (Solans, 2003). Beaver (2002) believes that financial innovation is an essential element for economic progress of a country and competitiveness of an industry. Sandvik (2003) argues that financial innovation is one of the most important competitive weapons generally seen as a firm's core value capability. Perhaps the core value system of a financial institution engineers its capability and ability to service customers of diverse tastes by utilizing the minimum available resources as asserted in the late 90's that Financial innovation is an effective way to improve firm's productivity due to the resource constraint issue facing a firm (Lumpkin \& Dess, 1996). This push-factor has forced banks to consider new ways to drive revenue through effective distribution system and continues products/services restructuring. The most common way to classify this is through the drive to increase the customer share of wallet. The share of wallet is the portion of a customer's entire financial relationship that any particular bank has with the customer. The primary revenue enhancing innovations occurring today are in platform automation for branch and phone center employees, and in the newest distribution channel, internet and mobile banking. While these innovations have some aspects in common, they each serve different needs in the distribution strategy of the banks (Mansury \& Love, 2008).

According to Nofie (2011) innovations in the finance sector is the arrival of a new or better product and/or a process that lowers the cost of producing existing financial services. Akamavi (2005) also notes that innovation in the financial services sector has led to recent fundamental changes including; deregulation, increasing competition, higher cost of developing new products and the rapid pace of technological innovation, more demanding customers and consolidation of corporations which we term as product of financial product/service metamorphosis.

The rise and fall of the financial market since the great depression have permanently splashed the spirit of working-over a constant and dynamic product/service divesting to edge future fears. This is why Desai and Low (1987) postulate that financial innovation is the method which can make the integrity of financial market come true using the Location Innovation Theory; an advanced financial innovation microscopic economic model that confirms and measures the gap in the scope of acquirable product in financial market, which indicates the potential opportunity of the new products' innovation and promotion. Chen (1995) built the financial intermediary model in which new security secured by old security is created. In the period of decomposing the old securities and opening new market, innovators play an influential economical role. For example, investors can obtain the consumption at lower cost; investors can realize a better share of risks. The model indicated that even when introducing the surplus securities which are not distributed yet, the innovators can also play these roles. In other words, although these innovations have not changed the scope of acquirable financial tools, it makes investor's trade at lower expected cost. These theoretical assertions point in the direction towards explaining the impact of financial innovation on financial performance.

\section{Perceived attribute of innovation in Today's Banking}

Rogers's theory of perceived attributes of innovation defines five characteristics of an innovation which have been shown to affect the rate of its adoption in a society (Cullen, 2001). However, Rogers (1995) mentioned that the rate of adoption is partially influenced by perceived attributes namely: relative advantage, compatibility, complexity, trialabilty, and observability. The degree to which the innovation is perceived to be superior to current practice or the degree to which an innovation is perceived as better than the idea it supersedes by a particular group of users creates relative advantage over others. According to Robinson (2009), it is measured in terms that matters to those users, like economic advantage, social prestige, convenience or satisfaction-the greater the perceived relative advantage, the more rapid the rate of adoption. But the relative advantage can not only be in isolation except the degree to which the innovation is perceived to be consistent with socio-cultural values, previous ideas and /or perceived needs is incompatible with a potential user's values, norms, or practices, it will not be adopted as rapidly as an 
innovation that is compatible especially when an innovation is perceived as difficult to use and understand. Such situation is hypothesized to be negatively related to the rate of adoption of an innovation (Rogers, 1995, 2003). It clear to note that, Innovations that are simpler to understand and use are adopted more rapidly compared to innovations that require the adopter to develop new skills and understanding. This will always give room for the innovation to be experienced on a limited basis by promoting the adoptability of an innovation thereby providing the opportunity for a potential user to experience using the innovation itself. The user gets the chance to try a technology without having to fully commit to purchase or adopt it. During this period, reinvention may occur. That is, the innovation may be changed or modified by the potential adopter, after which the results of an innovation are visible to potential adopters. The easier it is for individual to see the results of an innovation, the more likely they are to adopt it. Visible results lower uncertainty and also stimulate peer discussion of a new idea, as friends and neighbors of an adopter often request information about it.

According to Rogers (1995), the above characteristics determine between 49 and 87 percents of the variation in the adoption of any new product. These characteristics have also been used by researchers in different fields and have been discovered to predict the adoption of an innovation among the affected social system.

Studies from the early period of research on innovation have typically reported a positive relationship between innovation and measures of firm performance. In a new generation of models studying the impact of innovative activities on firm performance, the focus has shifted to the complex innovation process and channels through which the innovation inputs are transformed into better performance (Loof, Hans \& Heshmati 2002; Kemp, Folkeringa, Jong \& Wubban 2003; Bessler, Drobetz \& Gruninger 2008). The significance of financial innovation is described by Roberts and Amit (2003) as a means leading to a competitive advantage and superior financial performance. As revealed in many studies, financial innovation and firm financial performance have a positive relationship (example, Zahra \& Das, 1993; Capon, Farley \& Hoenig 1990; Calantone Vickery \& Droge 1995; Han Kim \& Srivastava 1998). Innovation would appear in product, process, market, factor and organization (Kao, 1989), but the first three dimensions are more familiar in the innovation literature (Johne \& Davies, 2000; Otero-Neira, Lindman \& Fernandez, 2009). Innovation generally does seem to have positive effects in raising financial performance of innovators (Boot \& Thakor, 2007). Crepon, Emmanuel and Jacques (1998) used a fourequation model, to link the innovation decision of firms to their performance through the impact of innovation input on innovation output and the innovation output on productivity and better performance. Their findings confirm the positive relationship between innovation activities and productivity at the firm level and provide further evidence on the relationship between size and innovation activities.

Innovation in Africa is a little slow but it is estimated that about $7 \%$ of internet users worldwide are in Africa with 167.3million Africans having access to the internet compared to 254.9million Latin Americans, half a billion Europeans and over 1 billion Asians. Internet penetration in Africa is 15.6\% versus a world average of $34.3 \%$. However Nigeria is Africa's top internet nation with 48.4 million internet users (Internet World Stats, 2012). In order to encourage e-payments and other alternatives to cash, the Central Bank of Nigeria (CBN) commenced a Cashless policy in Lagos State of Nigeria, as part of a wider shared services programme that seeks to achieve a $30 \%$ reduction in cost of banking services. Other objectives include increasing access, convenience and service levels across the industry; and integrating financial services into the economy (Ajiboye, Kalejaiye \& Dada, 2013). The volume and value of electronic card based transaction in 2010 were 195.7 million and 1,072.9 billion respectively, ATM transaction accounted for 186.2 million (95.1\%) and 954 billion (88.9), followed by internet banking 7.2 million (3.7\%) and 99.5 billion (9.3), mobile banking 1.2 million $(0.6 \%)$ and 6.7 billion $(0.6 \%)$ and POS 1.1 million $(0.6 \%)$ and 12.7 billion (1.2\%) in volume and value respectively. Similarly, in 2011 volume and value of electronic card based transaction increases to 355.2 million and 1,671.4 billion respectively. ATM recorded increase to 347.6 million (97.9) and 1,561.8 billion (93.4\%), internet banking decrease to 3.6 million (1\%) and 58 billion (3.5) while mobile banking 1.9 million $(0.5 \%)$ and 20.5 billion (1.2\%) and POS 
2.1 million ( $0.6 \%)$ and 31 billion (1.9\%) in volume and value respectively (CBN, 2011). These statistics evidence that, financial innovation has gradually crept into the Nigerian financial institutions and impacting favorably.

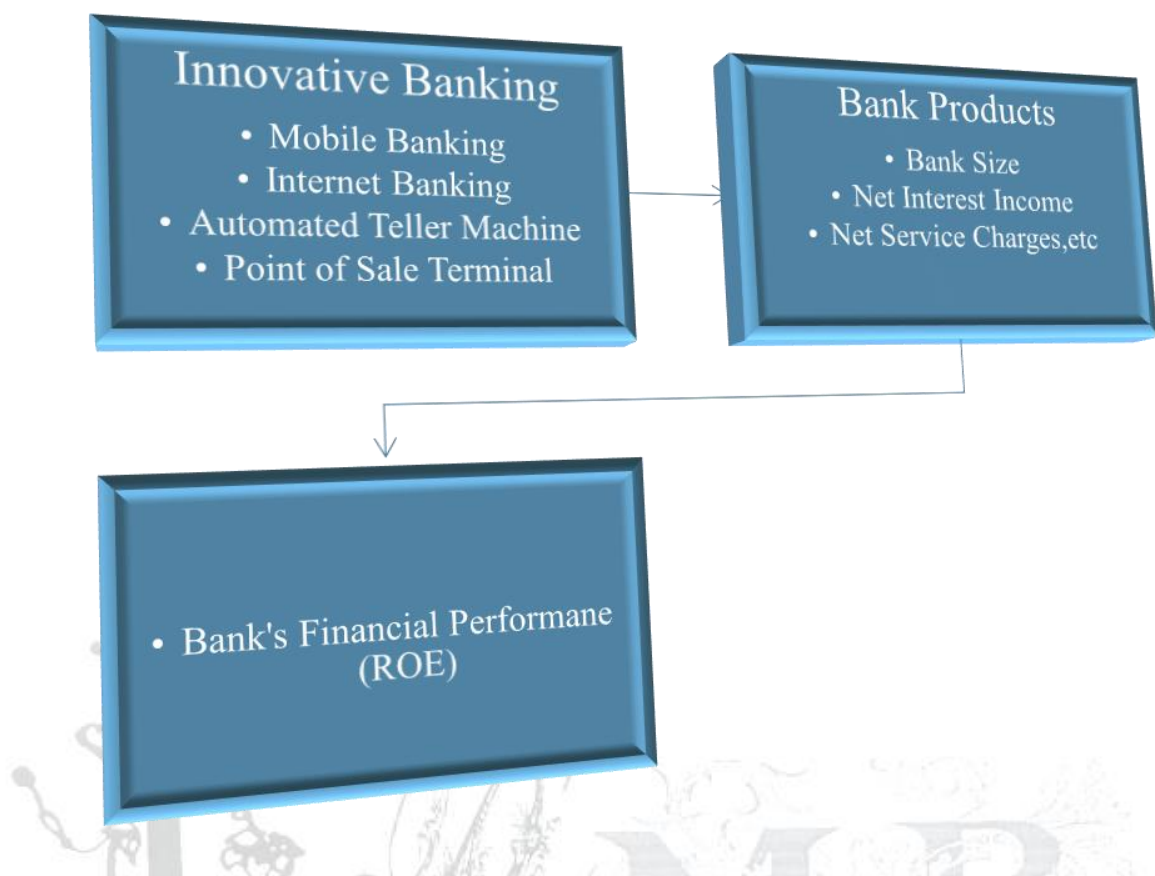

Figure 1: Conceptual Model of Financial Products on Bank performance Formulated from Empirical Reviews

From the discussions so far, we identify the independent variables of mobile banking, automated teller machine (ATM), online banking and point of sale terminal services as investigative influence on financial performance (return on equity). The relationship between the variables is what the schematic presentation in Figure 1 typifies. The assertion schemed above indicates that, Bank's financial performance is triggered by all available products that are promoted via the mobile, automated, internet and point of sales banking services which by extension improves rate of revenue generation though considering a banks size and earnings accruing.

\section{Methods and Model Specifications}

Ex-post facto research design was developed to determine the relationship between Bank innovative Services, i.e. financial Services distribution channels (i.e. automated teller machine, mobile banking, internet banking and point of sale service) and financial performance of Deposit Money Banks in Nigeria. We use data obtained from CBN annual reports, the annual reports, accounts, and inter-switch statistical information of the sampled Banks by measuring their performances in terms of returns on equity (ROE) for the years 2015-2016 long after the banks consolidation and thereby applying Stata 11.1 to analyze using regression technique. Prior to that, we observed the twenty one (21) Deposit Money Banks licensed by the Central Bank of Nigeria as at 2016 but utilized Sixteen (16) of them purposively selected without bias for representation in terms of progressive innovation. By this development, we engineered a model to accommodate the earlier identified varied variables of interest. 
The model established the relationship between financial services distribution channels, control variables and financial performance. This identified variables -automated teller machine, mobile banking, internet banking and point of sale service and financial performance were proxy by the number of ATMs, POS, internet availability and smart phone owners who bank with the 16 selected banks in Nigeria as provided in the CBN, Bureau of Statistics, individual banks, and newspaper reports and return on equity of individual banks from the period 2015 to 2016. The derivation of the regression relationship is the Bank Financial Performance (ROE) as a function of Bank size, Net Interest Income, Mobile Banking, ATM, Internet Banking and POS.

$$
R O E=f(B K S, N I I, M O B, \text { ATM, ITB, POS })
$$

The expansion of the functional equation above produces,

$$
\mathrm{ROE}_{\mathrm{i}}=\alpha_{\mathrm{i}}+\beta_{1} \mathrm{BKS}_{\mathrm{i}}+\beta_{2} \mathrm{NII}_{\mathrm{i}}+\beta_{3} \mathrm{MOB}_{\mathrm{i}}+\beta_{4} \mathrm{ATM}_{\mathrm{i}}+\beta_{5} \mathrm{ITB}_{\mathrm{i}}+\beta_{6} \mathrm{POS}_{\mathrm{i}}+\mu_{\mathrm{i}}
$$

Where:

$\mathrm{ROE}_{\mathrm{i}}=$ Financial performance (Return on Equity)

$\mathrm{BKS}_{\mathrm{i}}=$ Bank Size

$\mathrm{NII}_{\mathrm{i}}=$ Net Interest Income

$\mathrm{MOB}_{\mathrm{i}}$ Mobile banking

$\mathrm{ATM}_{\mathrm{i}}=$ Automated teller machine

$\mathrm{ITB}_{\mathrm{i}}=$ Internet banking

$\mathrm{POS}_{\mathrm{i}}=$ Point of sale service

$\alpha_{\mathrm{i}}=$ Constant value

$\beta_{1}-\beta_{6}=$ Coefficients of variables

$\mu_{\mathrm{i}}=$ Error term associated with variables

The correlation between the dependent and independent variables are presented in Table 1. The correlation matrix table shows the relationship between all pairs of variables in the regression model; the relationship between all explanatory variables individually with explained variable and the relationship between all the independent variables themselves. This gives an insight into the magnitude of the pairs of the independent variables.

Table 1: Correlation Matrix of Proxy Variables measuring the Co-linearity relationships for compatibility and influence on one another's properties to the behavior of another generated from sources enumerated and subjected to test-run.

\begin{tabular}{|c|c|c|c|c|c|c|c|c|}
\hline Variables & ROE & ATM & ITB & MOB & POS & BKS & NII & VIF \\
\hline ROE & 1.0000 & & & & & & & 1.50 \\
\hline ATM & 0.6359 & 1.0000 & & & & & & 1.06 \\
\hline ITB & -0.2979 & -0.5789 & 1.0000 & & & & & 2.15 \\
\hline MOB & 0.6114 & & -0.2615 & 1.0000 & & & & 5.87 \\
\hline POS & 0.6257 & 0.4919 & -0.3015 & 0.5988 & 1.0000 & & & 3.28 \\
\hline BKS & 0.4270 & 0.6978 & -0.0766 & 0.5188 & 0.4329 & 1.0000 & & 1.07 \\
\hline NII & 0.6879 & -0.7610 & 0.5727 & -0.6138 & -0.6445 & -0.2452 & 1.0000 & 1.11 \\
\hline
\end{tabular}

Table 1 shows the correlation coefficients of the relationship between the dependent Bank financial performance, ROE and all other variables. The values of the correlation coefficient range from -1 to 1 . The sign of the correlation coefficient indicates the direction of the relationship (positive or negative), the absolute values of the correlation coefficient indicates the strength, with larger values indicating stronger 
relationships. The correlation coefficients on the main diagonal are 1.0, because each variable has a perfect positive linear relationship with itself.

The correlation results presented in table 1 also indicate that five of the explanatory variables, ATM, Mobile banking, Point of sales, Bank Size and net interest income are positively correlated with the return on equity while Internet banking is negatively correlated with the return on equity. Similarly, the relation between some of the explanatory variables is positive and some negative. However, their Co-linearity are related, the multi-co-linearity of the independent variables or predictors are correlated implying interdependence among the predictors. For example, only ATMs and BKS show some degree of high multi-co-linearity of 0.6978 indicating the adverse affects of the predictive ability of the two variables. To determine the presence of co-linearity problem, a Variance Interest Factor (VIF) test was carried out, the results of which provide evidence of the absence of co-linearity show that from a minimum of 1.06 to a maximum of 5.87 VIF of 10.00 can still be a proof of absence of co-linearity (Doane \& Steward 2007, Muhammad 2009, Barde 2009 \& Samaila 2014). Hence, the predictive ability of the independent variables is not adversely affected by the relationship.

\section{Results and Discussions}

The result on table 2 indicates that the four predicting variables were able to explain $89 \%$ of the model $\left(\mathrm{R}^{2}=\right.$ .89). The multiple linear regressions shows that among the predicting variables, mobile, internet and point of sale banking are not significant in terms of their coefficients as proven by their probabilities of 0.599 , 0.488 and 0.497 , respectively. This means that, their power to predict the actual behavior of financial innovation performance is not so clear during the short-run. But further evidence provided by the joint probability F-test shows that all the variables impact on financial performance at $1 \%$ significant level (i.e. 0.0103) in the long-run. Therefore, the finding of the study reveals that there is no significant relationship between Mobile, internet and point of sale Banking and financial performance of Deposit Money Banks in Nigeria during the short-run except in the long-run. Also, a correlation coefficient of $0.005 \%$, indicates that increase in mobile banking transactions and or decrease (i.e. $-0.015 \%$ and $-0.012 \%$ ) of Internet and Point of sale services, respectively will not lead to improvement in financial performance of Deposit Money Bank in Nigeria during the short-run. This is consistent with the findings of Kisaka, Ndii, Muriki and Muio (2015).

Furthermore, we observe that the cumulative value of $\mathrm{R}^{2}=0.8923$ is the multiple coefficient of determination that gives the proportion or percentage of the total variation in the dependent variable explained jointly by the explanatory variables. This signifies that $89.23 \%$ of total variation in ROE (Bank Financial Performance) of listed Nigerian Deposit Money Banks is caused by the Mobile banking transactions, Automated Teller Machine (ATM) transactions, Internet banking transactions, bank Size and net interest income of the banks.

Similarly, the P-Value of 0.0103 implies that the model is fit and significant at $1 \%$ level. In addition, the results also reveal a positive relationship between the ATMs and the financial performance of deposit money banks in Nigeria- a trend that is statistically significant at $1 \%$ level. On the other hand, mobile banking reveals a positive relationship while internet banking and point of sale service have negative relationships with ROE but statistically insignificant.

Bank size measured as the natural logarithm of total assets is also found to be positively related with the financial performance (return on equity). This is because larger banks are expected to have achieved economy of scale and as such have the higher tendency to operate at lower cost hence obtains higher profit. Also the net interest income has a positive relationship with financial performance and this relationship is statistically significant at $1 \%$. 
By and large, it is event to note that a unit increase in the number of the daily transactions using ATMs $(\beta=$ 9.6006, $\mathrm{t}=50.18, \mathrm{P}<0.013$ ) will lead to 9.60 unit increase in the financial performance of the Deposit Money Bank clearly reporting on ATM transactions as a positive and significant influence on the ROE of listed Nigerian DMB's, similar trends are obtainable with the bank size and net interest income.

Table 2: Regression Result showing the relationship between the Bank Financial Performance proxy by Returns on Equity and the Innovation Services cum products necessitating revenue generation abilities of banks in Nigeria.

\begin{tabular}{|c|c|c|c|c|}
\hline Variables & Coefficient & Std. Error & T & P-value \\
\hline Constant & 374.6198 & 3.889 & 96.31 & $0.007^{*}$ \\
\hline MOB & 0.000477 & 0.000653 & -0.73 & 0.599 \\
\hline ATM & 9.6006 & 1.9107 & 50.18 & $0.013^{*}$ \\
\hline ITB & -0.001488 & 1.2716 & 1.04 & 0.488 \\
\hline POS & -0.00123 & 0.001225 & -1.01 & 0.497 \\
\hline BKS & 3.5138 & 0.0624 & 56.32 & $0.007^{*}$ \\
\hline NII & 37.55052 & 0.39397 & -95.31 & \\
\hline R-square & \multicolumn{3}{|c|}{0.8923} & 0.5694 \\
\hline Adjusted R-square & & 0.0103 & \\
\hline P-value & & 50.88 & \\
\hline F-value & & &
\end{tabular}

*significant@1\%

The negative relationship between internet banking and financial performance is consistent with the findings of De Young (2001) who found that pure internet oriented banks have poor financial performance as confirmed by Carlson et al (2001) assertion that internet utilizing banks have no independent impact on profitability except with other services.

In the same vein, Sathye, (2005) found that internet banking does not have a significant impact on performance and risk profile. However, it is contrary to the findings of Malthora and Sighn (2009) who concluded that internet oriented banks are larger in term of operating efficiency and profitability ratios as documented also by Sullivan (2000) that the novo click and mortar performed significantly worse than novo brick and mortar banks as a result of internet usage. Finally, the negative coefficient for the POS is consistent with the findings of Kisaka, Ndii, Muriki and Muio (2015).

\section{Conclusion}

We evident that financial innovation in payment systems result to improved financial performance of Deposit Money Banks except for internet banking and Point of Sales whose use is less end have less impact on Nigerian bank customers. Otherwise, a very strong and robust evidence for positive relationship between return on equity of the Deposit Money Banks and ATMs, Mobile Banking, Bank size and Net Interest Income as Financial innovation services/products present more conveniences, efficient and secured ways of conducting transactions which resulted to more demand for more financial innovations.

Internet transaction, Mobile transaction and Point of Sale transaction have not significantly improved the financial performance of Deposit Money Banks probably owing to some system failures, literacy and affordability problems. However, Banks in Nigeria have continued to perform well as explained by the use of innovations which have enabled banks to generate more income away from traditional sources like interest, trade and asset financing just as commission from transactions done on innovation channels especially ATMs runs into millions. 


\section{References}

Ahmad, H. K., Raza, A., Amjad, W. \& Akram, M. ( 2011). Financial Performance of Finance Companies in Pakistan. Interdisciplinary Journal of Contemporary Research in Business 2 (12), 732-744.

Akamavi, R. K. (2005). A Research Agenda for Investigation of Product Innovation in the Financial services sector. Journal of Services Marketing, 19(6), 359-378.

Alam, H. M., Raza, A. \& Akram, M. (2011). Financial Performance of Leasing Sector. The Case of China. Interdisciplinary Journal of Contemporary Research in Business , 2 (12), 339-345.

Al-Hussein, A. H. \& Johnson, R. L. (2009). Relationship Between Corporate Governance Efficiency and Saudi banks' performance, The Business Review, 14. 1, 111-17.

Ajiboye, O., Kalejaiye, O. \& Dada, O. (2013). Electronic Payments and Economic Growth in Nigeria. A Report by RTC Advisory Services Ltd. June 2013.

Batiz-Lazo, B. \& Woldesenbet, K. (2006). The Dynamics of Product and Process Innovation in UK banking. International Journal of Financial Services Management, 1 (4), 400-421.

Barde., I. M. (2009). An Evaluation of Accounting Information Disclosure in the Nigeria Oil Marketing Industry. (Unpublished PHD thesis) Bayero University Kano, Nigeria.

Beaver, G. (2002), Small Business, Entrepreneurship and Enterprise Development. Pearson Education Ltd, United Kingdom.

Bessler, W., Drobetz, W. \& Gruninger, M. (2011) Information Asymmetry and Financing Decisions. International Review of Finance 11, 123-154.

Boot, A. \& Thakor, A. (2007). Banking Scope and Financial Innovation. Review of Financial Studies 10, 1099-1131.

Calantone, R. J., Vickery, S. K. \& Droge, C. (1995). Business Performance and Strategic New Product Development Activities: An Empirical Investigation. Journal of Product Innovation Management, 12, 214-23.

Capon, N., Farley, J. U. \& Hoenig, S. (1990). Determinants of financial performance: a meta-analysis: Journal of Management Science 36 (10), 1143-1159.

Carlson J., Furst K., Lang W. W. and Nolle., D. E. (2001). Internet Banking: Market Developments and Regulatory Issues. Manuscript, the Society of Government Economists, Washington D.C.

Central Bank of Nigeria (2011). Annual Report \& Statement of Accounts. Retrived November $3^{\text {rd }}, 2015$ from http://www.cenbank.org

Central Bank of Nigeria (2015). List of Deposit Money Banks of Nigeria. Retrived January $14^{\text {th }}, 2016$ from http://www.cenbank.org

Chen, Z. (1995). Financial Innovation and Arbitrage Pricing in Frictional Economies. Journal of Economic Theory, 65, 15-22.

Crepon, B., Emmanuel, D. \& Jacques, M. (1998). Research, Innovation, and Productivity: An Econometric Analysis at the Firm Level. August 1, NBER Working Paper No. W6696

Cullen, R. (2001). Addressing Digital Divide. IFLA Proceedings 67th Council and General Conference. Boston: IFLA

De Young., R. (2001). "The Financial Performance of Pure Play Internet Banks". Economic Perspectives. Vol. 25 No. 1, pp. 60-75.

Desai, M. \& Low, M. (1987). Measuring the Opportunity for Product innovation, in M.de Cecco (de.), Changing Money: Financial Innovation in Developed Countries. Basil Blackwell, Oxford, 1987.

Doane., K. \& Steward., A. (2007). The Role of Electronic Banking on Financial Performance: Evidence from Listed Banks in Kenya.

Gorton, G., \& Metrick, A. (2010). Securitized Banking and the Run on Repo. Yale school of management, Working Paper.

Han, J. K., Kim, N. \& Srivastava, R. K. (1998). Market Orientation and Organizational Performance: Is Innovation a Missing Link? Journal of Marketing, 62 (4), 30-45.

Johne, A. \& Davies, R. (2000). Innovation in Medium-Sized Insurance Companies: How Marketing Adds Value. International Journal of Bank Marketing, 18 (1), 6-14. 
Kao, J. J. (1989). Entrepreneurship, Creativity and Organization: Test, Cases and Reading. Prentice Hall, New Jersey.

Kemp, R. G., Folkeringa, M., Jong, J. P. \& Wubben, E. F. (2003). Innovation and Firm Performance. Journal of Management 2 (4), 12-18.

Kisaka., S. E., Ndii., G. M., Muriki., M. \& Muio., K. (2015). The Relationship between Mobile Banking Deepening and Financial Performance of Commercial Banks in Kenya.Research Journal of Finance and Accounting, Vol.6, No.10.

Loof, M., Hans, S. \& Heshmati, J. (2002). Knowledge Capital and Performance Heterogeneity: A FirmLevel Innovation Study. International Journal of Production Economics. 2002, 76, 61-85.

Lerner, J. (2006). The new financial thing: The origins of financial innovations. Journal of Financial Economics, 79, 223-255.

Lumpkin, G. T. \& Dess, G. G. (1996). Clarifying the Entrepreneurial Orientation Construct and Linking It to Performance. Academy of Management Journal, 21 (1), 135-72.

Lyons, R. K. \& Chatman, J. A. (2007). Innovation in Financial Services: Corporate Culture and Investment Banking. California Management Review, 50(1), 174-191.

Malthora., P. \& Singh., B (2009). The Impact of Internet Banking on Bank Performance and Risk: The Indian Experience. Eurasian Journal of Business and Economics, 2 (4), 43-62.

Mansury, M. A. \& Love J. H. (2008). Innovation, Productivity and Growth in US Business Services: A Firm-level Analysis. Technovation, 28(1/2), 52-62.

Muhammad, L. M. (2008). Managerial Ownership, Board Structure and Firm Value: Evidence from Listed Oil Companies in Nigeria. An Unpublished PhD Dissertation (Accounting Department) Bayero University, Kano Nigeria.

Nofie, I. (2011). The Diffusion of Electronic Banking in Indonesia, Manchester Business School.

Otero-Neira, C., Lindman, M. T. \& Fernandez, M. J. (2009). Innovation and Performance in SME Furniture Industries: An International Comparative Case Study. Marketing Intelligence \& Planning, 27 (2), 216232.

Roberts, P. W. \& Amit, R. (2003). The Dynamics of Innovative Activity and Competitive Advantage: The Case of Australian retail Banking, 1981 to 1995. Organization Science, 14 (2), 107-122.

Robinson L. (2009), A Summary of Diffusion of Innovations. Retrieved from http://www.enablingchange.com.au/Summar y_Diffusion_Theory.pdf (Access online, May 2012).

Rogers, E.M. (1995). Diffusion of Innovation 4th ed. New York: the Free Press, 1995.

Rogers, E. M., (2003). Diffusion Innovation( $5^{\text {th }}$ Ed.) New York: the Free Press.

Sandvik, I. L. (2003). 'The Impact of Market Orientation on Product Innovativeness and Business Performance. International Journal of Research in Marketing, 20 (4), 255-376.

Sathye., M. (2005). The Impact of Internet Banking on Performance and Risk Profile: Evidence from Australian Credit Unions. The Journal of International Banking Regulation, Vol. 6 No. 2, February.

Solans, E. D. (2003) Financial Innovation and Monetary policy. Excerpts of Speech Delivered at the $38^{\text {th }}$ SEACEN Governors Conference and $22^{\text {nd }}$ Meeting of the SEACEN Board of Governors on Structural Change and Growth Prospects in Asia Challenges to Central Banking Manila (13 February 2003). http://host.uniroma3.it/eventi/wolpertinger2009/37.

Sullivan., R. J. (2000). How Has the Adoption of Internet Banking Affected Performance and Risk at Banks? A Look at Internet Banking in the Tenth Federal Reserve District. Financial Industry Perspectives, Federal Reserve Bank of Kansas City, December, pp. 1-16.

Zahra, S. A., \& Das, R. (1993). Innovation Strategy and Financial Performance in Manufacturing Companies: An Empirical study. Production and operations management Journal, 2(1), 15-37. 